\title{
Between Sociology and the Business School: Critical Studies of Work, Employment and Organization in the UK
}

\begin{abstract}
This is a paper about what happens when a form of knowledge moves to another part of the university. The author, identifying himself as an 'ex-sociologist', investigates the relationship between the sociology of work, employment and organization and various 'critical' traditions within the business school. I argue that the contemporary divide between sociologies of work and employment, and Critical Management Studies (CMS) within the business school rests in part on developments in UK sociology in the 1960s and 70s. This means that divergent understandings of the role of sociology and its relevant theoretical resources provided the deep structure for the current tension between CMS on the one hand and research on work and employment on the other. The movement of sociologists and industrial relations academics to the business school provided the preconditions for two very different critical traditions. The paper concludes with thoughts on what it means to be an outsider inside an institution, and on the future prospects for Burawoy's 'critical' or 'public' sociologies in UK business schools.
\end{abstract}




\section{Between Sociology and the Business School: Critical Studies of Work, Employment and Organization in the UK}

It seems evident that the prospects for Burawoy's 'critical' and 'public' sociologies (2005a) are in part determined by the institutional location of sociologists themselves. That is to say, what counts as critical is in part an organizational question, a question of 'how institutions think' (Douglas 1987) and what sort of sociology can exist within the post-Fordist university (Holmwood 20I I). This paper is specifically concerned with the relationship between critical sociology as it has emerged since the 1960s and various critical developments within the contemporary business school' I I argue that the divide between sociologies of work and employment, inside and outside the business school, and the rise of Critical Management Studies (CMS) within the business school, rests in part on developments in UK sociology from the 1960s onwards. It seems to me that bifurcated understandings of the role of sociology and its relevant theoretical resources provide the deep structure for the tension between CMS on the one hand and industrial relations and the sociology of work and employment on the other. The movement of sociologists to the business school, combined with the shrinking of sociology, has provided the precondition for a two very different critical traditions. Neither are 'at home' within the business school, but neither can agree on very much else.

There is no necessary reason to imagine the sociology of work, employment and organizations as a critical domain. Indeed, given that it usually studies those elements of the social which most often benefit the powerful - its economic institutions - it might be said that it was an area of social science which was quite likely to be conservative. Unlike work on deviance, gender, class or whatever, the study of work does not seem to have to begin with questions of violence, exclusion and power, and could instead be focussed on stability and the reproduction of existing structures. As a sociology student in the late 1970s, I remember thinking of it as the dullest area of the discipline - a series of taxonomies of organizations of different kinds, supplemented with endless debates about bureaucracy. It was a chapter in the textbook for those too timid to engage with the thrilling and urgent matters of crime, revolution and popular culture. This was clearly not a fair judgement, but it seems fair to say that it was one which was widely shared.

In this paper I will consider how, in the last forty years or so, the sociology of work, employment and organizations has moved from being perhaps an unfashionable area of sociology to providing some of the impetus for a now huge critical research project within the business school. Of course, as things travel, so do they change, because that which arrived in the business school was not the same as that which left sociology. Some issues seem to have been forgotten, others have assumed a centrality which they didn't previously have. To make matters more complex, an important element of this work has roots in a discipline which has long had a tense relationship with sociology - industrial relations. The connections between a sociology of organizations, the sociology of work and employment, and industrial relations are complex, and I will attempt to disentangle them a little here. The purpose of this essay is to understand a little more clearly how the history of critical work on work, employment and organization shapes its manifestations in the contemporary business school. Nowadays, this migration of people and knowledge is increasingly forgotten within the place itself, as new PhDs are socialised within a 'tradition' which they experience as substantially indigenous and handed down by professors who they only know as always having worked within this glittering new building.

One caution is necessary before I begin, in that I want to emphasise that this paper is about the British experience and is written by an author who identifies as an ex-sociologist who now works in a business school. It reflects some specifically British assumptions about the 
proper domains of sociology in the 1970s, the existence of a differentiated body of knowledge called industrial relations, as well as the simultaneous shrinking of sociology departments and growth of the business schools from the 1980s onwards. It shouldn't need saying, in an essay that is attempting to historicise knowledge, that sociology is not the same everywhere, not everything called 'sociology' began a decline in the 1980s, and business schools grew in different places at different times. Nonetheless, the British experience is important here, largely because it has had such a big influence on the growth of CMS. Not exclusively of course, because there are plenty of examples of key CMS figures who were not educated in Britain, and have never worked in Britain. But if we allow for some generalisation (given that any history will always fracture into different stories when pushed) then this is also the story of how North Western European CMS came to have the concerns that it does. A question that remains is just how critical work within the business school might develop over the next thirty years, and I will offer some thoughts on that towards the end of the paper.

\section{Departures}

By the mid 1970s, sociology in Britain was in part a critical project. Stanislav Andreski (then Professor of Sociology at the University of Reading) puts the idea well, in a dictionary of modern thought.

'critical sociology. An expression which in principle is a pleonasm, since all good SOCIOLOGY must be critical in the sense of insisting on probing and being ready to challenge current opinions. It is only because the main current of sociology has become apologetic that the justification for 'critical sociology' has arisen.' (in Bullock and Stallybrass 1977: 146)

The University of Reading closed its sociology department in 2008, forty years after the 1968 conference of the American Sociological Association saw the publication of The Insurgent Sociologist, becoming the journal Critical Sociology in 1969 (Fuller 1996, Burawoy 2005b). Reflecting the social and cultural turbulence of the 1960s, sociology had become a home for Marxism, critical theory and feminism, as well as forms of thought and method which began with the everyday, such as ethnomethodology and interactionism. The former trilogy quite explicitly challenged the timeless institutions of the bourgeoisie - the family, the legal system, education - and rewrote them as places in which the powerful produced compliant citizens. Sociologies of action and language had a less explicit politics, but it seems that they were often understood to be suggesting that if the social world was constructed from the ground up then it could be changed from the ground up too, almost as if sociology were some giant breaching experiment.

It seems important to locate these critiques in the 1960s, because it is at that point that the university and the knowledge it produces becomes a terrain for explicit dissent. Against Daniel Bell's characterization of a 'cow sociology' (1956: 25) ${ }^{2}$ which provided knowledge about mass behaviour for the power elite, there were consistent demands to articulate sociology as a project which responded to civil rights, anti-war, women's and student's movements in the US (Colfax and Roach 197I, Fay 1987, Fuller 1996: 2, Burawoy 2005a), to which we might add a politics of class in the UK. Though much British sociology continued in its substantially empirical and theoretically pragmatic manner (Savage 2010), the tumult of criticism aimed at 'functionalism' effectively meant that by the 1970s most textbooks proceeded in the following three part schema. Introduce a topic, and then describe it in terms of the consensual functions it plays in advanced societies, possibly with reference to Durkheim, Merton, Shils, Parsons or similar figures. Then reverse the assumptions and describe it from the viewpoint of conflict assumptions, invoking various feminists and Marxists as evidence. Finally, show how everyday interaction (within the classroom, on the beat, in the hospital) reproduces the assumptions about expertise, gender, or the role of the media. Though in theory functionalism maintained its place, in practice it was challenged 
both politically and conceptually, with the challengers having the benefit of novelty and seeming more in touch with the spirit of the times. The fourth edition of Stephen Cotgrove's The Science of Society (originally published in 1967 as the first UK student sociology text ${ }^{3}$ ) notes that when the first edition came out 'one perspective - structural functionalism - was widely (though not universally) accepted among sociologists as an explanatory framework holding considerable promise.' However, he goes on to say, recently 'its critics have argued (rightly or wrongly) that it paid insufficient attention to conflict and change, and painted a too determinist picture of the relation between man and society.' (Cotgrove 1980: 7)

This was precisely the set-up into which British sociology students of the 1970s and 1980s were being socialised. It was one in which exciting new developments in politics and theory were being seen to overturn the dull conservativism of the founding fathers, a diagnosis that nicely chimed with a counter-cultural politics which was firmly embedded from the 1960s onwards. Margaret Coulson and David Riddell's Approaching Sociology from 1970, is worth quoting at some length.

'It is our view that sociology is potentially a humanistic discipline in that it can increase the area of choice men have over their actions. It can enable them to locate the sources to which they must go if they wish to change things, and the necessary means, thus providing man with a potential scientific basis for action, increasing him, rather than cramping him into a straight jacket of determinism provided by explanations in terms of how he 'fits in' to the social order' (107)

This idea that sociology was 'humanist' was a common one, perhaps inspired by Peter Berger's Invitation to Sociology which was published in the UK in 1966, and went through twelve reprints in the next decade. In it, Berger suggests that the sort of sociology he was to later define as social construction was capable of showing the puppets their strings. However -

'Unlike the puppets, we have the possibility of stopping in our movements, looking up and perceiving the machinery by which we have been moved. In this act lies the first step towards freedom. And in this same act we find the justification of sociology as a humanistic discipline.' (1966: 199)

Whether this was an accurate characterisation isn't really the point - it was a common understanding of the ways in which British sociology was being articulated in opposition to power, constraint and inauthenticity. For those studying sociology in Britain from (say) 1965 to 1985, this was the intellectual milieu into which they were socialised. In terms of the sociology of work, employment and organizations, this was a context in which David Silverman's Theory of Organizations outlined what a 'social action' model might look like, later describing it as situated against 'functionalism' and 'abstracted empiricism' (1970, 1994). A few years later Braverman's Labor and Monopoly Capital (1974) insisted on the importance of a Marxist account of the labour process, decrying human relations as a form of knowledge that did no more than accommodate the worker to their subordination. So when two big British books come along within a year of each other - Burrell and Morgan's Sociological Paradigms and Organizational Analysis (1979) and Clegg and Dunkerley's Organization, Class and Control (1980) - they both reflect this impatience with conventional accounts. Indeed, the former book embeds a story about the dominance of one 'paradigm', and the need for its critique by other 'paradigms'. In other words, structural Marxism, radical humanism and sociologies of action challenge the dominant but dead versions of structural functionalism.

These are forms of Manichean thought in which opposition is constitutive of identity. I am not suggesting that all sociology was actually like this, or that structural functionalism was as dominant as claimed or that its opposition quite so coherent and vocal, but this was a powerful story of paradigmatic crisis which those who had studied sociology took with them into the expanding UK business schools of the 1980s (Reed 1985). Some idea about what it 
meant to engage in 'critical sociology', as opposed to co-opted versions of 'professional' or 'policy' sociologies (Burawoy 2005a) seemed to be part of an account which constructed sociology as an inherently critical discipline. Yet, in the UK, it was also a discipline engaged in a long slow decline. As Holmwood observes, there were $6 \mathrm{I}$ submissions to the state Research Assessment Exercise in 1996. By 2008, this had fallen to 39 and sociologists were looking for employment elsewhere (Holmwood 20l0), Just as the sociology departments were beginning to shrink, so were other parts of the university beginning to grow rapidly. The labour market for sociologists to teach in their 'home' departments was shrinking, and so they became émigrés, working in medical faculties; social work and policy departments; schools of education, criminology and development studies. But by far the biggest demand was from the 'organizational behaviour' parts of business schools, which needed a labour force to teach the 'people and organizations' core courses on undergraduate and postgraduate degrees with very healthy enrolments, including substantial cohorts of non-UK students who were paying full fees and were providing universities with new ways to earn money in an increasingly straitened funding environment ${ }^{4}$. So the jobs were there, and for those who followed the money, and arrived in these alien parts of the university, my contention is that their commitments were often shaped by the sociology that they had left behind.

\section{Arrivals}

If anything, the Manichean shape of the sociology that they had learned was likely to be exacerbated in the new conditions in which they found themselves. For some, the Marxists who had commitments to developing a labour process critique of capitalism, this opposition was political in the sense that they found themselves working in institutions which tended to orient themselves to management rather than worker. Not that they were the first to arrive, because industrial relations (IR) academics were some of the first inhabitants of the British business school. As lan Roberts notes, the development and institutionalisation of industrial relations as a discipline really happens in the 1920s and 1930s, whilst sociology only grows from the 1950s onwards (2003: 34 ). There are some clear tensions between IR and industrial sociology from this later period, with the beginnings of an account that sociologists are not interested in structures and institutions, but only in what happens at particular places of work. Two IR academics understand sociology to be a 'school' which '... applies the techniques of sociology and social psychology direct to 'situations' which it discovers in factories and other places of work ... [However] much of its published work shows a deplorable lack of historical understanding and, sometimes, a failure to appreciate the nature of the 'situation' studied due to ignorance of the framework of formal institutions which surround it' (Flanders and Clegg 1956, in Roberts 2003: 34)

In that sense, the sociologist is being understood as the inheritor of a human relations account of adjustment to the workplace, as opposed to a rigorous understanding of the history and consequences of formal mechanisms for regulating conflict (Brown 1992: 25 passim). The sociologist then, at this moment, is not seen as the inheritor of a critical tradition at all, but an arriviste stooge for the bosses whose job is to ensure that happy cows produce more milk.

This initially uneasy relationship seems to have become less problematic as industrial sociologists and industrial relations academics began to be employed within business schools from the 1970s onwards. Probably the most influential aspect of the former had been the 'orientations to work' Weberianism of the affluent worker and occupational community studies (Rose 1978, Eldridge 2009). Crucially, this was research which was being carried out at the level of an organization or occupation, and which was attempting to develop an empirically driven account of the way that meaning influences action. It wasn't that far from a conflict Weberian account to a Marxist one, and hence unsurprising that industrial 
sociologists and industrial relations academics influenced by Alan Fox's criticisms of pluralism (1974) should begin to find shared intellectual ground. Questions concerning gender, skill and restructuring came to the forefront and Braverman's 1974 book provided a new intellectual resource with which to rediscover some old problems. The Labour Process conferences which began in 1983 at business schools in new technology universities in Manchester and Birmingham began to institutionalise this accommodation, even if there was remarkably little reflection on its contradictory location (Rowlinson and Hassard 201 I: 675). The BSA journal Work, Employment and Society began publishing in 1987 to provide a location for the sort of work which brought together sociologists in sociology departments, feminists who were enlarging the concept of work beyond employment, sociologists who were now working in business schools, and industrial relations academics. So productive was this new alliance in its new location that it was recently possible for some key figures in the field to echo Flanders and Clegg half a century on in stating that now 'it is mainstream sociology that is in crisis, and need of renovation' (Thompson and Smith 2009: 926)

Yet, and this is a point of crucial importance, a lot of the sociologists who moved were not Marxist or Weberian industrial sociologists, but were perhaps more influenced by the cultural critique of the Frankfurt School, various sociologies of action, and the philosophies of what came to be called post-structuralism. It was much harder for this group to find anything in common with industrial relations or the sociology of work and employment, even though they might have shared an understanding of the importance of meanings at work with the latter. It seems to me that this is why 'organization' became such a key term, as opposed to what seem like bigger words such as 'work', 'industry' and 'employment'. A focus on the concept of 'organizing' allowed for several things. First, to connect to a tradition of largely US interactionist work on organizing from authors such as Garfinkel, Berger and Luckmann, Goffman and Becker. Second, to turn elements of Weberian and Frankfurt school understandings of bureaucracy and mass society into a diagnosis of the predicament of Whyte's Organization Man (1956). Third, to place language at the centre of their enquiries, and consequently to connect to thinkers from 'outside' the empirical social sciences, such as Derrida and Foucault. Nonetheless, it seems to me that this latter group also preserved a sense of themselves as being 'in opposition' to their employers. That sense of not being endogenous provided a certain sort of distance from the goals and values of the business school, as well as a developed body of knowledge which was external to the school, and which could provide the resources for critique.

The institutionalization of this second sense of 'critical' work happens gradually, but fairly inexorably as conferences, journals and associations are established. The first meeting of the Standing Conference on Organizational Symbolism took place in 1982, a breakaway group from the more orthodox European Group for Organization Studies ${ }^{5}$, and was originally jointly organized and attended by people from sociology and the business school. However, by the third conference in 1984, it was clear that SCOS was dominated by attendees from the business school, though its concerns have continued to reflect the influence of microsociologies, as well as structuralism and poststructuralism ${ }^{6}$. Other later conferences originate within the business school itself, such as the 'Discourse' conferences organized from Kings College Business School in London from 1994, the Gender, Work and Organization conference at UMIST and then Keele from 1998, and the CMS conference from Manchester School of Management in 1999. The journals that were established in this period also tended to be dominated by academics from business schools - such as Organization (1994), Gender, Work and Organization (1994) and Culture and Organization (1995). All were justified in terms of their difference from the mainstream, whether that was a neglect of certain sorts of themes, or an active contestation of dominant approaches.

The crystallization of something called Critical Management Studies in the mid 1990s was unsurprising in this context, as was the way in which it demonstrated the difficulty of making 
a tent big enough to hold interactionists, Frankfurt School Marxists and poststructuralists alongside sociologists of work and employment and industrial relations academics. The very Habermasian edited volume that inaugurated CMS named a sub-disciplinary field (Alvesson and Willmott 1992), not merely a tendency or area of interest. All but one of its contributors were working in management schools, and the explicit claim made in the introduction to this volume concerns the application of critical theory to management, and the avoidance of a 'sociologism' which would dissolve the specificity of CMS into a more general understanding of 'ideological and cultural phenomena' (op cit: 18). Like other critical projects in the social sciences (Parker and Thomas 20II) the prefix was vital, but so too was the idea that this could be a generic area of study. There is an interesting balancing act being engaged in here, with an attempt to claim that CMS is not the same as sociology, its most obvious parent, but neither is it part of the business school. Just like Durkheim's attempt to claim that the new discipline of sociology was not psychology, history, philosophy, anthropology or political economy (1895/I982), so do Alvesson et al have to claim that the domain of CMS is not sociology or management, but something new.

Over the past twenty years I would argue that the 'not management' part of this description has become the constitutive one, and any need to distance CMS from sociology has become irrelevant. This is in part because the labour market for staff to teach 'people and organizations' has now become pretty much internal to the business school, consisting of students who have been trained within it. This doesn't mean that those interested in CMS see its contents and purposes as settled, rather that their identity work remains Manichean, constituted oppositionally. The nature of the opposition varies - whether managerialism, managers, contemporary forms of organizing, the Deans of business schools, capitalism, vested interests and so on - but the narrative of struggle is common. Indeed, the amount of writing which has mediated upon the possibilities and co-optations of CMS is now vast, with the majority of it being arranged as a balancing act between pessimism of the intellect and optimism of the will (for example, the contributions to Calás et al 2008). The very existence of all this literature speaks of the instability and insecurity of the field, with each term 'critical', 'management' and 'studies' - being subjected to relentless interrogation. Some might read this as vibrancy, others as an endless concern to validate ${ }^{7}$.

Clearly not all work on people and organizations in the business school identifies itself as critical, and any conflation of CMS with organization studies in general doesn't work. Much organization studies is not hostile to the business school, and much of CMS is about accounting, marketing, strategy and so on. Nontheless, the growth of CMS has implications for the other 'critical' constituencies within the business school, particularly IR academics and sociologists of work and employment. Their response has generally not been positive. Indeed, the 1950s diagnosis of sociology by IR academics is now being re-run, but this time aimed at CMS for being too focussed on action at the neglect of structure; politically pluralist or unitarist, and largely doing work at the level of meaning and organization. Indeed, the restless reflexivity and theoretical neophilia which is characteristic of CMS could easily be understood as a recipe for political quietism which masquerades as intellectual radicalism (Parker 1999, Thompson, Smith and Ackroyd 2000, Rowlinson and Hassard 201 I). On the other hand, those who inherit sociologies of work and employment within the business school use particular terms in order to locate themselves - critical realism, materialist feminism, institutional theory, labour process theory - and which distance them from CMS (Thompson 2004). If we compare a journal such as Work, Employment and Society with Organization we can see the consequences of this. Two largely different groups, who go to different conferences and use different founding texts. Yet, and this is the biggest irony of all, both would largely claim to be 'critical' in the specific sense meant by Burawoy (2005a: 10), and pretty much all of them work in the business school. It seems that this is a state of affairs which proves that even academics who claim to understand such matters, and might 
look up to see the machinery which moves them, cannot escape the strings of history and discipline.

\section{Sociology within and without the Business School}

The migration of sociologists into the business school has nowadays now become a trickle, but this also reflects some changes in sociology itself. The sociology of work and employment, which in principle includes the sociology of organizations, was clearly a central part of classical sociology as it came to grips with what it meant to be modern. The capitalist employment relationship, the bureaucratic organization and the division of labour were central concepts for the development of sociology in Europe and North America (Parker 2000, Roberts 2003, Adler 2009). Indeed, in Britain, the post 1945 period sees something of a golden age for the sociology of work, particularly in terms of research into the intersections between class and work, studies of occupational communities, to which it might be added a great deal of micro-sociology which took the workplace as its object of interest (Savage 2010).

What appears to happen from the 1980s onwards is the beginnings of a decline of interest in work and organizations within sociology. Burawoy bemoans this happening in the US in the late 1970s (1979), but in the UK this tendency seems to be made more visible by the relative decline in the number of people working in sociology departments, set against a huge growth in the 'people and organizations' departments of business schools. To put it crudely, jobs and promotions were available in the business school, and they were not in sociology. However, this is not the whole story since, as Strangleman (2005) argues, there were substantial changes in work itself which made the golden age look increasingly dated. The increasing number of women in the labour market, the rise of flexible working and the distribution of organizations across space and time, high levels of unemployment and an aging population all began to make class based workplace studies less dominant in understanding work. In addition, the rise of a 'culturalism' within sociology, as well as of cultural studies itself, meant that the idea of the primacy or centrality of work was being actively contested. Ideas about production and the shop floor seemed to be giving way to an image of consumers operating in a society of symbols, and the sociologies of gender, youth and ethnicity made the idea of studying white men in factories look rather old fashioned. Indeed, as Parry et al (2005) argue, the very idea that 'employment' was still the only category which might be used to understand Miriam Glucksmann's 'total social organization of labour' (1995) was coming under severe strain.

All in all, this meant that the sociology of employment was less of a specific interest. Work and workplaces were often studied, but as part of a sociology of migration, the household, creative labour or whatever. New methods and new sites for the investigation of the social within sociology, combined with the increasing number of journals and conferences based in the business school from the 1990s onwards, meant that research on work and employment tended to move elsewhere ${ }^{8}$. So when the British Sociological Association started publishing Work, Employment and Society it was largely the growing number of sociologists and IR academics in business schools which provided the authors and readers'. Indeed, Thompson and Smith suggest that it was the Labour Process Theorists who 'played to and built on the strengths of British industrial sociology' (2009: 924). Whether we accept this rather narrow characterisation or not, the intellectual distinctions between those studying work and employment and those studying organizations then begin to become rather stark. For WES authors, increasingly based within business schools but having intellectual roots in industrial relations, labour process theory and materialist feminism the task was to empirically document questions of power and control. Development of new theory or methods was certainly not at the forefront of concern per se, and the concept of organization was assumed, ${ }^{10}$. This was work which usually took questions of work and employment to be 
addressable with empirical and comparative evidence. Crucially, the critical edge is almost always provided by the empirical materials with a broadly 'social scientific' justification for their selection, analysis and presentation.

Compare this with the tendencies in what was coming to be Critical Management Studies, in which the deployment of theory and the use of novel methodologies was becoming characteristic of journals such as Organization and Culture and Organization. Almost exclusively based in business schools, the development of interactionist and philosophically inclined work took 'the organization' as both a site for micro-social analysis of questions of identity, narrative and culture, but also problematized the idea of 'organizing' itself. Resistance to the very notion of there being rigid structures - of gender, class, occupation provides a metaphorical expansion of many arguments. We see ideas about language, method, thought, autonomy, authority and so on being rethought in terms of the overarching idea of organization as a verb, or even disorganization as a tactic and/or virtue itself. This did not exclude the possibility of empirical evidence, but instead privileged the theoretical as the site for critical work. It is not necessarily the structures of the world which should be the springboard for concern, but structures of thought - the habitual, the common sense, the taken for granted. The idea was to raise eyebrows, not to add evidence to the pile.

These characterisations of each 'side' will doubtless please neither, but I hope they capture something of the differences between two groups who would both claim to be doing 'critical' work. There is, of course, no one meaning of the word 'critical' (Fay 1987, Burawoy 2005b). It depends substantially on context. What might be critical in a business school might not be critical in a sociology department, and what might be critical in the US might not be critical in the UK'I. In order to understand dissent, we need to understand the dominant. That being said, the business school, as a context for dissent, has one key feature which is of considerable importance. This is a general tendency to be doing research for management rather than on management, usually because it is management students with aspirations to become managers, or research funders who want 'useful' knowledge, who pay the bills. It is rarely a good idea to insult your customers if you want repeat business, and hence such knowledge falls into Burawoy's characterisation and critique of 'policy' sociology (2005a: 9). It follows from this that the sort of thinking that the business school usually trades in tends to be conservative in its presentation and implications, and makes claims about its utility for busy people who want to get ahead in life.

So it seems that there are two critical traditions in the contemporary British business school, both indebted to sociology, and both in opposition to the context they find themselves in. It seems to me that it would be quite possible to evaluate this tricky set-up in two quite different ways. One is to say that there is nothing wrong with sociology in Business Schools as such, but that it should empirically document the injustices of the present and report them without fear or favour (Stewart 2004). This is a response which responds to the 'policy' context by insisting that the 'professional' structures of academic life provide the space for 'critical' enquiry. The second is to suggest that the problem is the very idea of teaching a science of control, and hence to question foundational assumptions about knowledge and representation (Parker and Thomas 20II). This would be to say that both the 'policy' and 'professional' contexts demand 'critical' interrogation and opposition. To be clear, I don't think that either of these approaches is right or wrong in some absolute sense, but I think that they can both be called critical in the context of the contemporary business school with its endowed chairs and sponsored lecture theatres. The first begins with evidence, by documenting the actually existing cruelties and inequalities of capitalism, patriarchy and imperialism, and builds its dissent in the shape of the world it finds. This is a politics of truth, in which the evasions and deceit of the powerful is contested with an account of what the world is 'really' like. The second begins with epistemology, insisting that 
the prison begins in the mind, and that there is a politics to the act of representation. The critical edge here then comes with an attempt to think and write differently, to open new possibilities for action and organizing which are constrained by a lack of imagination.

This, it seems to me, is the divide which structures critical work in UK business schools at the present time. The former, with its roots in IR and the sociology of work and employment, demands a balanced social science from the business school and insistently reminds us that knowledge might set us free. The latter, developing from sociology's mutation in the counter culture of the late 1960s, requires a rethinking of the very idea of the university itself, and claims that knowledge is always power.

\section{Institutionalization}

The story I have told about critical work on work so far is one that has relied on many overgeneralizations, and a line up which pitches 'macro' against 'micro', 'structure' against 'agency', a 50 year 'turf war' (Roberts 2003: 36) between industrial relations and sociology, and a migration from sociology to the shiny new business schools. It is also one which has involved the definition of terms as belonging to one side rather than another - 'work', 'employment', 'industry' versus 'organization' - and the deployment of labels with which to insult the other side, such as 'dualist', 'essentialist', 'relativist' or 'postmodernist'. It would be easy enough to play up the differences here, but what I want to do in this final section is to say something about similarities, and hence try to comment on the future prospects for the sociology of work, employment and organization after much of it has left the sociology department. It seems to me that there are threats to this sort of work as a whole which far outweigh the differences which might divide them.

One of the features of the arrangement which has provided both 'sides' with their intellectual energy over the past thirty years has been the tension between origins and destinations. Industrial relations and the sociology of work, employment and organizations are not indigenous to the business school. In fact, very little is, simply because this is such a recent settlement in intellectual and institutional terms in the UK. It is only over the last four decades that the business school has emerged in its modern form, well within the span of a single academic career. No wonder then that there are many migrants who don't feel quite at home - whether they be from economics, mathematics, psychology or wherever. This sense of estrangement was doubled for those who moved from sociology simply because these were domains which had been hugely influenced by the counter cultural currents of Marxism, feminism, critical theory and poststructuralism. UK sociologists were certainly not influenced by all of them in the same way, as I have suggested above, but enough to share a sense of being alien to the increasingly managerial missions of schools which were becoming cash machines for universities dealing with dwindling state support.

Nowadays, business schools have become substantial institutions in their own right, in a global labour market for students and staff. For those engaged in studying work, employment and organization this makes for a very comfortable situation, because in most institutions there are more jobs in this single area of the business school than in the whole of the sociology department. Business schools now produce their own PhDs, are internally divided in ways which label these topics as matters to be studied by the 'organizational' behaviour/analysis/studies/theory or the HRM/IR people'2, and these employees have generated a predictable range of journals, conferences, professional associations and texts which legitimate an enquiry into these areas as something which belongs in the business school. ${ }^{13}$ Yet, as is obvious, there are risks in such 'success', and it seems necessary to think hard about the conditions for critical work, whether that be IR, the sociology of work and employment, or CMS. This is particularly important at the time of writing, when it seems that the effective privatization of UK universities is making them even more attentive to the 
markets that they sell into, and hence even less enthusiastic about alienating possible sources of revenue - be they students, alumni, grant funders, policy makers or anyone from the 'real world' who thinks they know what business schools ought to be doing.

Given these pressures, how can 'critical' work on work survive? It seems to me that criticism, in the most general sense of a questioning of the value of a particular practice seems most likely to come from outside the institution that houses that practice. When words like 'co-optation' or 'recuperation' are being used, they reflect that sense of a losing of a dissenting status and the taking on of the values associated with the centres of power. In the arts, this is the moment when the avant garde sells out and follows the money; in politics it is the moment when the entryists get seduced by the glittering prizes. This doesn't mean that criticism can't come from within an institution; merely that it is less likely to do so. One of the further implications here is that it is in the early years of institutional formation that we might expect to find more heterodoxy, as a diverse range of interests and forms of understanding are being brought together. Put simply, there is less agreement on what 'we' should be doing because the whole idea of a 'we' is a problem.

This is a general description of the early years of the business school in the UK, as it pulled a diverse range of disciplines together in order to produce a new settlement (Eldridge 2009). Intellectual baggage from elsewhere was being deployed in a new context, and for some this was a matter of an orientation to social scientific knowledge in general. If you had been trained in a form of industrial relations which predated the business school by half a century, and which had been re-shaped by Marxism since the 1970s, then the business school presented itself as predictably managerial. If you had been trained in a counter cultural sociology which pitched action against structure, and critique against orthodoxy, then the business school looked very much like an example of the ideological state apparatus or working for the man. No wonder that there has been so much hand wringing, though more on the CMS side than the work, employment and IR, because accusations of hypocrisy were so hard to avoid, and accounts of integrity so difficult to maintain.

The threats to critical understandings are rarely direct in the sense of a besuited Dean telling someone what they cannot do, more a matter of a gradual redescription. As Elger (2009: 1002) notes, there is a danger of a 'mainstreaming' or 'dilution' of understandings of work and employment if it ends up in business schools, and the complexities of human action becomes reduced to behaving in organizations, or the management of human resources (Brown 1992: 32). This would be a viewpoint which neglects the importance of a broad understanding of the politics of working life, both for students, teachers and researchers. This moves us towards the unitarist social psychology which reproduces the complaint made by Flanders and Clegg concerning the human relations school in the 1950s. Questions of leadership, change, culture and structure are approached as if there were no politics to knowledge, about who controls resources and gets rewards. Even when pluralist in its assumptions, a great deal of work on identity, narrative, discourse and so on can be understood as fiddling while Rome burns, and certainly is by many industrial sociologists and IR academics. These are often studies of how management and professionals feel about things, which are precisely the sort of jobs that business school graduates hope to occupy. For IR itself, the slide into the business school has very often meant that studies of trade unions and collective bargaining have gradually been displaced by the 'cow sociology' of personnel and HRM. Departments have changed their names, and a social psychological HRM has emerged which often intellectually and politically converges with the discursive version of organization studies.

Now as I have already acknowledged, there is no transcendental critical position, which is perhaps just why the disputes over who can own and use such a label and what it might mean are so bitter. So when Rowlinson and Hassard (both professors in UK business 
schools), ruminate on the problems with the 'critters' (an US term for CMS academics) and characterise them as 'disaffected academic drifters' (20I I), its hard not to imagine that they are describing themselves too. Since this paper is concerned with critical work on organizations in the UK, then it must also - necessarily - understand critical positions as having some relation to history, identity and institutions. And when it comes to these matters, no-one can claim to be outside everything, and to see clearly who is pulling their strings.

That being said, and as I hope this paper has shown, the gradual congealing of the business school has involved bringing intellectual assumptions from other places and I think it is precisely this partial sense of 'self-estrangement' which has provided the impetus for so much work within it (Fay 1987: 10). Whether industrial relations, industrial sociology, or the post 1970s sociologies of action and language, the key issue is that something was imported which didn't fit with the increasingly imperial and strident rhetoric which surrounded the rise of managerialism. This paper isn't concerned to debate the merits of critical realism or the latest French theorist, but it is important to note that both have provided a way to redescribe management, business and markets in ways that are less concerned to flatter power. This is in part because they use forms of legitimacy which were developed in other places and can hence remember a different way of thinking from sociology and industrial relations. But if we were to look at the next fifty years of the business school can we imagine such a vibrant range of 'not-management' thought? Can the business school develop its own immanent critique?

After noting that not all academic work in business schools is necessarily managerial, Halford and Strangleman, two British sociologists who are interested in organizations, ask -

'Nonetheless, sociologists should ask what knowledge is produced under these conditions and what type of sociologist is produced in such circumstances. (...) The danger here is that the sociological imagination that exists in business schools is almost bound to be diluted through generational shifts, organizational structural development, and recognition and reward strategies. If we look to the business schools to produce future generations of sociologists of work then we would be complacent to expect a set of people interested in, and with a commitment to, a wider sociology.' (2009: 819) Halford and Strangleman know that we can't go back to a golden age, and must acknowledge the fragmentation of sociology and the necessity of inter-disciplinarity, but at the same time insist that we mustn't allow 'the collapse of disciplines into indistinctiveness' (op cit: 82I). They celebrate 'a strong sense of discipline' and insist that 'real interdisciplinary research and writing comes best from those secure in their own field' (op cit: 822). They don't say anything about criticality as such, but instead fall back on the (now hallowed and hollowed out phrase) the 'sociological imagination'.

There is a really important insight here, but I don't agree with Halford and Strangleman that there is something particularly special about sociology as such. There isn't, and we should assume that any imperialistic or nostalgic claim about disciplinarity should be treated with suspicion. Sociologists have no particular monopoly on imagination, and it is not the queen of the sciences. But what Halford and Strangleman have implicitly suggested is that critical work comes from an awareness of not being at home, and that suggests that any institution that congeals, and which begins to produce inhabitants who have never been anywhere else, is in danger of losing the possibility of critical understanding. What could you know of the business school, if it's only the business school that you know? Interestingly, calls for a public sociology (Burawoy 2005a), as well as a tempered optimism about the dispersal of sociological inscriptions into social life more generally (Osborne et al 2008: 532) rather miss the point precisely because they neglect the institutional context, the form of work organization, which harbours the people who produce that knowledge. The comparative neglect of work, employment and organization within sociology is reflected in a failure to 
emphasise the institutional structuring of sociological knowledge. The case of the UK business school proves that the sociological diaspora have had influence elsewhere, but whether that influence can endure over time is an open question. Holmwood's pessimistic general diagnosis of 'Sociology after Fordism' seems entirely appropriate to describe a possible trajectory of critical sociological knowledge in the business school. Indeed, as the history I have described here becomes forgotten, and sociology becomes distant from the concerns of those who are at home under the glass atrium -

'...the most likely consequence is neither the reproduction of a professional core, or of polycentric, self-reflective critical sociologies, but the expansion of the mode two knowledge of applied social studies. Once sociological interests in explanation and critique are denied, all that remains is to serve the interests of our "co-producers". The post-Fordist university is the university of "applied (social) studies"...' (20II: 55I)

\section{References}

Adler, P (ed) (2009) The Oxford Handbook of Sociology and Organization Studies. Oxford: Oxford University Press.

Alvesson, M, and Willmott, H, (eds), (1992), Critical Management Studies. London: Sage.

Barley, S and Kunda, G (200I) 'Bringing Work back in’ Ortganization Science I2: 76-95.

Bell, D (1956) Work and its Discontents. Boston: Beacon.

Berger, P (1966) Invitation to Sociology: A Humanistic Perspective. Harmondsworth: Pelican.

Bottomore, T (1963) Sociology: A Guide to Problems and Literature, London: George Allen and Unwin.

Braverman, H (1974) Labor and Monopoly Capital. New York: Monthly Review Press.

Brown, R K (1992) Understanding Industrial Organizations. London: Routledge.

Bullock, A and Stallybrass, O (1977) The Fontana Dictionary of Modern Thought. London: Fontana.

Burawoy, M (1979) Manufacturing Consent. Chicago, IL: University of Chicago Press.

Burawoy, M (2005a) ‘For Public Sociology’ American Sociological Review 70: 4-28.

Burawoy, M (2005b) 'The Critical Turn to Public Sociology' Critical Sociology 31/3: 313-326.

Burrell, G, and Morgan, G, (1979) Sociological Paradigms and Organisational Analysis. London: Heinemann.

Calás, M, Morgan, G and Smircich, L (2008) 'Speaking Out on the Future of Critical Management Studies' Organization 15/6: 911-945

Clegg, S, and Dunkerley, D, (1980), Organisation, Class and Control. London: Routledge and Kegan Paul.

Colfax, J and Roach, J (eds) (197I) Radical Sociology. New York: Basic Books. 
Cotgrove, S (1980) The Science of Society: An Introduction to Sociology. London: George Allen and Unwin.

Coulson, M and Riddell, D (1970) Approaching Sociology: A Critical Introduction. London: Routledge and Kegan Paul.

Douglas, M (1987) How Institutions Think. London: Routledge and Kegan Paul.

Durkheim, E (1895/I982) The Rules of Sociological Method. Basingstoke: Macmillan.

Eldridge, J (2009) 'Industrial Sociology in the UK: Reminiscences and Reflections' Sociology 43/5: 829-845.

Elger, T (2009) 'Teaching the Sociology of Work and Employment: Texts and Reflections' Sociology 43/5: 997-1006.

Fay, B (1987) Critical Social Science. Ithaca, NY: Cornell University Press.

Fox, A (1974) Beyond Contract: Work, Power and Trust Relations. London: Faber and Faber.

Fuller, A (1996) 'Producing Radical Scholarship: The Radical Sociology Movement, 1967-

1975', Sociological Imagination 33/I, http://comm-org.wisc.edu/si/fuller.htm, accessed I7/I/I2.

Glucksmann, M (1995) 'Why "Work"? Gender and the "Total Social Organization of Labour" Gender, Work and Organization 2/2: 63-75.

Halford, S and Strangleman, T (2009) 'In Search of the Sociology of Work: Past, Present and Future' Sociology 43/5: $81 \mathrm{I}-828$.

Holmwood, J (2010) 'Sociology's Misfortune: Disciplinarity, Interdisciplinarity and the Impact of Audit Culture', British Journal of Sociology 61/4: 639-58.

Holmwood, J (201 I) 'Sociology after Fordism: Prospects and Problems' European Journal of Social Theory 14/4: 537-556.

Parker, M (1999) 'Capitalism, Subjectivity and Ethics: Debating Labour Process Analysis', Organization Studies 20/I: 25-45.

Parker, M (2000) 'The Sociology of Organizations and the Organization of Sociology: Some Reflections on the Making of a Division of Labour', Sociological Review 48/I: I24-I46.

Osborne, T, Rose, N and Savage, M (2008) 'Reinscribing British Sociology: Some Critical Reflections' Sociological Review 56/4: 519-534.

Parker, M and Thomas, R (20II) 'What is a Critical Journal?' Organization [1350-5084] I8/4: 4l9-427.

Parry, J, Taylor, R, Pettinger, L and Glucksmann, M (2005) 'Confronting the Challenges of Work Today: New Horizons and Perspectives', in Pettinger, L, Parry, J, Taylor, R and Glucksmann, M (eds) A New Sociology of Work. Oxford: Blackwell/Sociological Review.

Reed, M (1985) Redirections in Organizational Analysis. London: Tavistock. 
Roberts, I (2003) 'Sociology and Industrial Relations', in P Ackers and A Wilkinson (eds) Understanding Work and Employment: Industrial Relations in Transition. Oxford: Oxford University Press, 32-42.

Rose, M (1978) Industrial Behaviour, Harmondsworth: Penguin.

Rowlinson, $\mathrm{M}$ and Hassard, J (20I I) 'How come the critters came to be teaching in business schools? Contradictions in the institutionalisation of critical management studies' Organization 18/5: 673-689.

Savage, M (2010) Identities and Social Change in Britain since 1940. Oxford: Oxford University Press.

Silverman, D (1970) The Theory of Organizations. London: Heinemann.

Silverman, D (1994) 'On throwing away ladders: re-writing the theory of organizations', in J Hassard and M Parker (eds) Towards a New Theory of Organizations. London: Routledge, I-23.

Stewart, P (2004) 'Work, Employment and Society Today', Work, Employment and Society 18/4: 653-662.

Strangleman, T (2005) 'Sociological futures and the sociology of work', Sociological Research Online, 10/4. www.socresonline.org.uk/ /0/4/strangleman .html

Thompson, P (2004) 'A critical reflection on Critical Management Studies'. In Fleetwood, S and Ackroyd, S (eds) Critical Realist applications in Organization and Management Studies. London: Routledge, 54-70.

Thompson, P and Smith, C (2009) 'Labour Power and Labour Process: Contesting the Marginality of the Sociology of Work' Sociology, 43/5: 913-930.

Thompson, P, Smith, C, and Ackroyd, S (2000) 'If Ethics is the Answer, You Are Asking the Wrong Questions: A Reply to Martin Parker', Organisation Studies, 21/6: I I49-I I58.

Whyte, W H (1956) The Organisation Man. New York: Simon and Schuster.

\footnotetext{
' Thanks to the very helpful reviews for this journal, as well as Glenn Morgan and Lynne Pettinger for comments.

${ }^{2} \mathrm{~A}$ term often associated with CW Mills, but seemingly originating with Bell. 'As one management consultant, Burleigh Gardner, succinctly phrased it: " The more satisfied [the worker] is, the greater will be his self esteem, the more contented he will be, and therefore, the more efficient in what he is doing." A fitting description, not of human, but of cow, sociology.' (1956: 25)

${ }^{3}$ If we discount Tom Bottomore's rather more advanced, and thoroughly Marxist, text from 1963.

${ }^{4}$ At the time of writing there are 117 full members of the British Association of Business Schools.

According to the British Sociological Association's website there are 30 departments of sociology, and a further eighteen departments with sociology in the name

(ww.britsoc.ac.uk/WhatlsSociology?WhereToStudySociology.htm, accessed I8/I/I2). Whilst other general social science departments also offer sociology programmes, it might also be noted that business schools tend to be rather large, whilst sociology departments are often quite small.

${ }^{5} \mathrm{~A}$ departure which underscores the importance of not conflating Organization Studies with CMS.

${ }^{6}$ Thanks to Pippa Carter, Norman Jackson and Deborah Kerfoot for information on SCOS and GWO.

${ }^{7} \mathrm{~A}$ characterisation which of course applies to this essay too.

${ }^{8}$ A generalisation which, as Strangleman 2005 demonstrates in his survey of new developments in the sociology of work, is not entirely true, but true enough. He resents this characterisation, but provides
} 
a great deal of evidence in his essay to support it. See also Halford and Strangleman 2009 for a similar diagnosis.

${ }^{9}$ Not exclusively, because there was plenty of work in sociology which was relevant, but I would argue that the intervening 25 years has seen the dominance of the business school over WES become clear.

${ }^{10}$ In the early 1990s, I was told by a WES editor that they didn't usually publish 'case studies', which seemed to mean studies based on a single organization. Stewart's 2004 editorial suggests 10\% of submissions were classed as 'case studies/organization studies' during his tenure, and also that WES did not want to 'cede the terrain' to 'economics, organization studies, work and occupational psychology' (654),

11 Though there are similarities with the US experience. See Barley and Kunda $200 \mathrm{I}$.

${ }^{12}$ All terms which are clearly not synonyms, but each reflect slightly different assumptions about lineages and audiences. See Brown 1992: 29 passim.

${ }^{13}$ Indeed, in the UK research assessment exercises, it seemed clear that sociology journals were not being given high scores in the Association of Business Schools list, a positive discouragement for business school academics to spend time publishing in them. 